\title{
Allelopathic compounds of a red tide dinoflagellate have species-specific and context-dependent impacts on phytoplankton
}

\author{
Kelsey L. Poulson ${ }^{1, *}$, R. Drew Sieg ${ }^{1, *}$, Emily K. Prince ${ }^{1}$, Julia Kubanek ${ }^{1,2, * *}$ \\ ${ }^{1}$ School of Biology, Georgia Institute of Technology, 310 Ferst Drive, Atlanta, Georgia 30332-0230, USA \\ ${ }^{2}$ School of Chemistry and Biochemistry, Georgia Institute of Technology, 901 Atlantic Drive, Atlanta, \\ Georgia 30332-0400, USA
}

\begin{abstract}
The use of chemical compounds to suppress the growth of competitors is a competitive strategy known as allelopathy that can be readily observed with many phytoplankton species in laboratory studies. However, it is unclear how these allelopathic interactions are altered when the complexity of the system is increased to more closely mimic natural conditions. In the present study, we conducted laboratory experiments to decipher how the identity, abundance, and growth stage of competitors affect the outcome of allelopathic interactions with the red tide dinoflagellate Karenia brevis. Multiple chemical compounds produced by $K$. brevis were found to inhibit the growth of 4 phytoplankton competitors, although these competitors were susceptible to different combinations of compounds. We found that physiological state and cell concentration of competitors were important determinants of allelopathy, with early-stage (lag phase) cells more vulnerable to allelopathic effects than later growth stages for the diatom Skeletonema grethae. Despite being allelopathic to multiple competitors in the laboratory, in a microcosm experiment using plankton field assemblages, extracellular extracts of 2 strains of $K$. brevis had no effects on some taxa although they stimulated the growth of some diatoms. This suggests that in a species-rich ecological community under oligotrophic conditions, the relative importance of $K$. brevis allelopathy may not be as high as most laboratory studies predict.
\end{abstract}

KEY WORDS: Allelopathy $\cdot$ Competition $\cdot$ Phytoplankton $\cdot$ Red tide

\section{INTRODUCTION}

In planktonic systems, the use of chemical compounds to kill or slow the growth of competitors, a process known as allelopathy, may confer a selective advantage to phytoplankton that are weak exploitation competitors (Adolf et al. 2006, Tillmann et al. 2008, Poulson et al. 2009). Many groups of phytoplankton, including dinoflagellates (Kubanek et al. 2005, Adolf et al. 2006, Tillmann \& Hansen 2009), haptophytes (Uronen et al. 2007), raphidophytes (Yamasaki et al. 2009), diatoms (Hansen \& Eilertsen 2007, Ribalet et al. 2007), and cyanobacteria (Suikkanen et al. 2006) are allelopathic towards co-occurring species. However, the effectiveness of phytoplankton allelopathy is affected by both biotic and abiotic factors, making it difficult to draw conclusions from simplified laboratory studies. The presence of specific competitor species can induce the production of allelopathic compounds (Vardi et al. 2002) or undermine the effectiveness of allelopathy (Prince et al. 2008b). Abiotic influences, such as nutrient concentrations, salinity, light intensity, and temperature, can affect allelopathic potency, as found for the haptophyte Prymnesium parvum (Graneli \& Salomon 2010). Additionally, allelopathic potency can vary among strains, as shown with the dinoflagellates Alexandrium ostenfeldii (Tillmann et al. 2008), Karenia brevis (Kubanek et al. 2005), and Karlodinium veneficum (Adolf et al. 2006), making it difficult to predict allelopathic outcomes of genetically diverse blooms. 
Although allelopathy is becoming increasingly appreciated based upon laboratory results, the relevance of allelopathy in ecological settings has been challenged, particularly in the process of bloom formation (Flynn 2008, Jonsson et al. 2009). A few micro- and mesocosm studies have shown that allelopathic effects can be observed within complex plankton communities, but these effects may be dampened depending on environmental conditions (Fistarol et al. 2004, Suikkanen et al. 2005). When studying allelopathy, pair-wise interactions between competitors are often investigated using extracellular extracts or cell-free filtrates (e.g. Kubanek et al. 2005, Prince et al. 2008a, Yamasaki et al. 2009), but it is unlikely that outcomes in a diverse plankton community will be accurately predicted from the sum of these pair-wise interactions. Additionally, most studies have utilized crude extracts or cell-free filtrates, which do not allow researchers to test for the presence of multiple allelopathic compounds of varying potency released by cells. However, in order to efficiently identify allelopathic compounds or the mechanism(s) by which these compounds affect competitors, simpler pair-wise laboratory experiments are invaluable. Overall, more field-based and multispecies studies of allelopathy and its role in community and bloom dynamics are needed in order to complement mechanistic laboratory-based investigations.

Karenia brevis is an allelopathic red-tide dinoflagellate that blooms most years in the Gulf of Mexico (Tester \& Steidinger 1997). Neurotoxic brevetoxins produced by $K$. brevis cause massive fish kills (Landsberg et al. 2009) and have been shown to accumulate in shellfish (Plakas et al. 2002), and trophic transfer of these compounds can result in marine mammal mortality (Flewelling et al. 2005). Nevertheless, these toxins do not appear to be responsible for allelopathy towards most phytoplankton competitors (Kubanek et al. 2005, Prince et al. 2008a). Previous studies showed that extracellular extracts and filtrates from both $K$. brevis cultures and blooms were allelopathic to multiple competitors, although some species were resistant (Kubanek et al. 2005, Prince et al. 2008a). K. brevis produces multiple allelopathic compounds (Prince et al. in press) which may allow $K$. brevis to suppress several competitors simultaneously. To further explore this hypothesis, we investigated the species-specificity of allelopathic compounds against a suite of susceptible phytoplankton.

Although multiple studies have demonstrated the allelopathic effects of Karenia brevis against individual competitor species, the relative importance of $K$. brevis allelopathy against a backdrop of other competitive interactions is unknown. To investigate this, a microcosm experiment was conducted in which the inhibitory effect of $K$. brevis extracts was tested on a nat- ural, non-bloom Florida plankton assemblage. Additionally, since $K$. brevis allelopathy can be undermined by other competitor species (Prince et al. 2008b), we investigated how species composition, growth stage, and cell concentration of competitors influence allelopathic potency.

\section{MATERIALS AND METHODS}

Phytoplankton culturing. Non-axenic clones of the diatoms Asterionellopsis glacialis (strain CCMP 137), Skeletonema grethae (CCMP 775), and Amphora sp. (CCMP 129); the dinoflagellates Akashiwo sanguinea (CCMP 1740), Prorocentrum minimum (CCMP 695), and Karenia brevis (CCMP 2228, hereinafter '2228') were obtained from the Provasoli-Guillard National Center for Culture of Marine Phytoplankton (CCMP). An additional strain of $K$. brevis (TxB3, hereinafter 'TxB3') was obtained from Texas A\&M University. All cultures were maintained at $22^{\circ} \mathrm{C}$ with a $12 \mathrm{~h}$ light: $12 \mathrm{~h}$ dark cycle in a Percival incubator with Philips F32T8/TL741 Universal/Hi-Vision fluorescent bulbs mounted vertically, producing irradiance of 100 to $145 \mu \mathrm{mol} \mathrm{m} \mathrm{m}^{-2} \mathrm{~s}^{-1}$ (Biospherical Instruments, model QSL2100). All phytoplankton cultures were grown in L1 + silicate media made with $0.2 \mu$ m filtered natural seawater from Boothbay Harbor, Maine, USA (salinity $35, \mathrm{CCMP}$ ). Seawater was stored in the dark at $5^{\circ} \mathrm{C}$ until use. Growth curves and cell concentrations were generated using an Olympus IX-50 inverted microscope with a Palmer-Maloney settling chamber on culture samples preserved with acidified Lugol's solution.

Generation of extracellular extracts. To obtain extracellular extracts of Karenia brevis cultures used in high-performance liquid chromatography (HPLC) and subsequent species-specificity experiments (see 'Testing species-specificity of allelopathy'), a mixture of 3 adsorbent resins that remove lipophilic organic molecules from aqueous media were added to $K$. brevis cultures that were in exponential growth stage $\left(3.5 \times 10^{3}\right.$ to $1.6 \times 10^{4}$ cells $\mathrm{ml}^{-1}$; sensu Prince et al. 2006). This method allows for the extraction of lipophilic compounds released by cells into the media without extracting intracellular material. For all other experiments, a modified protocol was used to reduce the potential for false positives. These extracellular extracts were obtained by adding 2 resins (XAD -7 and HP-20, Supelco) to cultures of $K$. brevis while they were in mid- to late exponential growth stage $\left(9.8 \times 10^{3}\right.$ to $3.0 \times 10^{4}$ cells $\mathrm{ml}^{-1}$ ), and incubated for 12 to $15 \mathrm{~h}$. To clean the resins prior to addition into phytoplankton cultures, both resins were rinsed once with HPLCgrade acetone and 8 times with HPLC-grade methanol. Residual solvents were removed from resins with 
deionized water. The resins were removed with gentle filtration through Nitex nylon mesh and rinsed with sterile seawater to remove any cells potentially remaining on the resins. Compounds were eluted from the resins using 3 rinses of HPLC-grade methanol after a seawater and deionized water rinse. An extract of $0.2 \mu \mathrm{m}$ filtered, sterile Maine seawater was also generated in this manner for controls. A $48 \mathrm{~h}$ allelopathy bioassay using Asterionellopsis glacialis was performed as described in 'Testing species specificity of allopathy' to determine which $K$. brevis cultures were allelopathic. The 6 most allelopathic extracts of $K$. brevis 2228 were combined to yield enough extract for experimental use. Preliminary tests of the extracts demonstrated that $K$. brevis 2228 was allelopathic to $A$. glacialis, but neither $K$. brevis TxB3 nor seawater extracts inhibited $A$. glacialis growth (data not shown).

Purification of allelopathic compound(s) exuded by Karenia brevis. HPLC fractionation of extracellular K. brevis extracts: To test the species-specificity of $K$. brevis allelopathy, a pooled crude extracellular extract of $K$. brevis 2228 was tested against 5 phytoplankton species. $K$. brevis 2228 extract was fractionated using a Waters 1525 binary HPLC pump and a Waters 2487 dual-wavelength detector set at 215 and $254 \mathrm{~nm}$, coupled to Waters Breeze software. We used a $\mathrm{C}_{18}$ reversed-phase silica column (Zorbax SB-C18, $4.6 \times 250$ $\mathrm{mm}, 5 \mu \mathrm{m}$ particle size) and a flow rate of $1 \mathrm{ml} \mathrm{\textrm {min } ^ { - 1 }}$ with a mobile phase of methanol:water (1:3) ramped to $100 \%$ methanol over $60 \mathrm{~min}$, resulting in 27 peaks. Nine fractions were created by pooling an aliquot of each peak in groups of 3 . These 9 fractions were then tested for allelopathic activity using the bioassay described in the following section. Two of these 9 fractions were allelopathic, and so the 6 compounds (A to F) that composed these 2 fractions were used in subsequent bioassays to determine the species-specificity of $K$. brevis allelopathy.

Testing species-specificity of allelopathy: To balance the need for statistical power with keeping the number of experimental units manageable, 3 or 4 individual treatments were blocked with each control. On the first day of the experiment, 7 replicate tubes containing $2.8 \mathrm{ml}$ of media were inoculated with $200 \mu \mathrm{l}$ of phytoplankton culture (Asterionellopsis glacialis, Amphora sp., Skeletonema grethae, or Prorocentrum minimum). With the slower-growing Akashiwo sanguinea, tubes containing $2.0 \mathrm{ml}$ media were inoculated with $1.0 \mathrm{ml}$ culture. Cell concentrations in each tube were approximated using a Turner Designs TD-700 fluorometer calibrated with chlorophyll $a$ as described in Prince et al. $(2008 \mathrm{a}, \mathrm{b})$. To account for compound decomposition during fractionation, each tube received twice the natural concentration of compounds exuded by Karenia brevis (i.e. $3 \mathrm{ml}$ of competitor culture received the amount of fraction obtained from $6 \mathrm{ml}$ of $K$. brevis culture). Assays using crude extracts were conducted using natural concentrations of extract. Extract was dissolved in $5 \mu \mathrm{l}$ dimethylsulfoxide (DMSO) and added to treatment tubes; solvent control tubes received DMSO only ( $\mathrm{n}=7$ tubes treatment ${ }^{-1}$ ). Treatments were blocked by replicate and haphazardly placed in the incubator. Tubes were inverted daily. Approximate cell concentration in each experimental tube was assessed after $48 \mathrm{~h}$ using in vivo fluorescence (after $96 \mathrm{~h}$ for Akashiwo sanguinea). Percent growth of competitors in each tube was calculated using:

$$
\begin{aligned}
& \% \text { growth of competitor }(48 \mathrm{~h})= \\
& \frac{\text { final fluorescence }- \text { initial fluorescence }}{\text { initial fluorescence }} \times 100
\end{aligned}
$$

In order to compare between treatments from different blocked groups, normalized growth was calculated to result in growth relative to controls using:

$\%$ growth relative to control $=$

$\left(1-\frac{\% \text { growth of control }(48 \mathrm{~h})-\% \text { growth of treatment }(48 \mathrm{~h})}{\% \text { growth of control }(48 \mathrm{~h})}\right) \times 100$

Statistical analyses: The percent growth of each treatment after $48 \mathrm{~h}$ was compared within groups using a 1-way ANOVA with Tukey's HSD post hoc test using SYSTAT 9 ( $\mathrm{p}<0.05)$ (Zar 1999). After running 1-way ANOVA on a single block, Eq. (2) was used to plot growth data from multiple blocks in a single figure, but this normalized data was not analyzed in the 1-way ANOVA. In Figs. 1, 2 \& 4, in which where significance is denoted by an asterisk, treatment growth is significantly different relative to control growth in their respective blocks.

Plankton community response to Karenia brevis allelopathy. Collection of natural non-bloom plankton assemblages: Natural plankton assemblages were collected from a pier on St. Charles Island, Florida $\left(29.6725^{\circ} \mathrm{N}, 84.8633^{\circ} \mathrm{W}\right.$, salinity 23 , sea surface temperature $16.5^{\circ} \mathrm{C}$ ) in December 2009 using a conical phytoplankton net (10 $\mu \mathrm{m}$ mesh, $1 \mathrm{~m}$ depth vertical tow, $\mathrm{n}=6$ tows). Mesozooplankton were removed by filtering samples through $150 \mu \mathrm{m}$ Nitex nylon mesh. K. brevis was not observed in these samples. After each tow, concentrated plankton samples were brought to twice natural densities using glass fiber-filtered Gulf of Mexico seawater (salinity 23).

Microcosm preparation: To determine how allelopathy alters plankton community structure, Florida assemblages were exposed to Karenia brevis extracts from either the non-allelopathic TxB3 strain or the allelopathic 2228 strain. Controls were exposed to seawater extracts. The 6 diluted tow samples were each split into 3 treatment bottles $(400 \mathrm{ml}, \mathrm{n}=6$ replicates treatment $t^{-1}$ ). Each replicate within a treatment came 
from a separate tow. Bottles were incubated at Georgia Institute of Technology $\left(22^{\circ} \mathrm{C}, 12 \mathrm{~h}\right.$ light:12 h dark cycle). Extracts of seawater or $K$. brevis equivalent to $400 \mathrm{ml}$ of culture were added to replicate bottles using DMSO as a carrier solvent (667 $\left.\mu \mathrm{l} \mathrm{bottle}{ }^{-1}\right)$.

Data collection and analysis: Replicate bottles were sampled prior to addition of extract and after $48 \mathrm{~h}$ exposure. To measure changes in community structure, $5 \mathrm{ml}$ aliquots of acid Lugol's preserved samples were settled in Utermöhl settling chambers for $20 \mathrm{~min}$, and diatoms, dinoflagellates, and microzooplankton were enumerated. Other plankton groups were not used in analysis due to inadequate abundances. Diatoms were further classified into pennate and chain diatoms. Genera of diatoms from a subset of bottles were identified.

The growth of chain diatoms, pennate diatoms, dinoflagellates, and microzooplankton over $48 \mathrm{~h}$ was used to determine the effects of Karenia brevis extracts on the assemblage. Prior to analysis, growth of each plankton group was converted using:

$\%$ growth of plankton group $(48 \mathrm{~h})=$ $\frac{\text { Cell concentration }(48 \mathrm{~h})-\text { Cell concentration }(0 \mathrm{~h})}{\text { Cell concentration }(0 \mathrm{~h})} \times 100$

The percent growth of each plankton group after $48 \mathrm{~h}$ across treatments was compared using a 1-way ANOVA with Tukey's HSD post hoc test ( $\mathrm{p}<0.05)$. Paired $t$-tests were conducted to compare mean cell densities of the different plankton groups in a given treatment between $0 \mathrm{~h}$ and $48 \mathrm{~h}$. Statistical analyses were conducted using JMP 8 (SAS).

Testing allelopathic outcomes with phytoplankton co-cultures. To test whether competitors could influence each other's susceptibility to allelopathy, crude extracellular extracts of Karenia brevis were tested for allelopathic activity against Asterionellopsis glacialis and Skeletonema grethae in co-culture, using a $48 \mathrm{~h}$ allelopathy assay. Cultures were grown to mid-exponential growth phase $\left(3.0 \times 10^{5}\right.$ cells ml ${ }^{-1}$ and $1.4 \times 10^{5}$ cells $\mathrm{ml}^{-1}$ for $S$. grethae and A. glacialis, respectively), and exposed to $K$. brevis 2228 or seawater extract at natural concentrations as described for the speciesspecificity assay. Tubes contained $S$. grethae monocultures, A. glacialis monocultures, or a co-culture of $A$. glacialis and $S$. grethae $(5 \mathrm{ml}, \mathrm{n}=8)$. To prepare co-culture treatments, $2.5 \mathrm{ml}$ of each competitor was added to each replicate tube, resulting in a final total cell concentration similar to that in monocultures. Cultures were incubated for $48 \mathrm{~h}$ and measured for changes in fluorescence. After each measurement, an aliquot of culture from each tube was preserved to determine cell concentrations and relative proportions of both algal species (proportional data were arcsine-trans- formed prior to statistical analysis). Percent growth of cultures was calculated using Eq. (1). Statistical differences in growth were determined using an unpaired $t$-test.

Effects of competitor cell concentration and growth stage on Karenia brevis allelopathic potency. To determine if the susceptibility of Skeletonema grethae to $K$. brevis allelopathy is contingent on $S$. grethae cell concentration, various cultures of $S$. grethae were exposed to K. brevis 2228 extracts. Three cell concentrations of $S$. grethae were used in this experiment: 'High', average concentration $(1.50 \pm 0.26) \times 10^{6}$ cells $\mathrm{ml}^{-1}$; 'Medium', average concentration $(4.14 \pm 0.22) \times$ $10^{4}$ cells $\mathrm{ml}^{-1}$; and 'Low', average concentration (5.57 \pm 1.23) $\times 10^{3}$ cells ml ${ }^{-1}$. K. brevis and seawater extracts were added at natural concentrations ( $\mathrm{n}=10$ for all treatments). Cell concentration was approximated via fluorescence, and percent growth over $48 \mathrm{~h}$ was calculated using Eq. (1). An unpaired t-test was used to compare growth of $S$. grethae at a particular concentration exposed to $K$. brevis extract from cells exposed to seawater extract. A 1-way ANOVA with Tukey's HSD post hoc test $(\mathrm{p}<0.05)$ was used to compare the growth of different densities of $S$. grethae exposed to seawater or $K$. brevis extract.

To test whether cell growth stage is important in determining the susceptibility of Skeletonema grethae to Karenia brevis 2228, S. grethae cultures were grown until reaching either lag, exponential, or stationary growth stages and then centrifuged 3 times (5 min, $4000 \mathrm{rpm}$ ) to pellet cells, rinsing with sterile seawater between spins to ensure the removal of excess nutrients from media. The cells were re-suspended in sterile seawater, aliquots were transferred into tubes, and brought up to a final cell concentration that mimicked that of cultures in lag phase, i.e. $(5.41 \pm 3.90) \times 10^{5}$ cells $\mathrm{ml}^{-1}, 3 \mathrm{ml}$ final volume, ensuring that tubes contained S. grethae cells of differing physiological state at equal cell concentrations. A new batch of $K$. brevis 2228 extract was generated for this experiment, and either 2228 or seawater extracts were added, growth was measured, and statistical analyses were run as described for the cell-density experiment in the previous paragraph.

\section{RESULTS}

\section{Karenia brevis is allelopathic to multiple phytoplankton species}

Multiple competitors were inhibited by Karenia brevis 2228 extracellular extracts (Fig. 1). Diatoms Amphora sp., Asterionellopsis glacialis, and Skeletonema grethae all experienced decreased growth 
relative to controls when exposed to allelopathic $K$. brevis extracts for $48 \mathrm{~h}$, with $A$. glacialis and $S$. grethae suffering negative growth whereas Amphora sp. growth was impaired but still positive (all p <

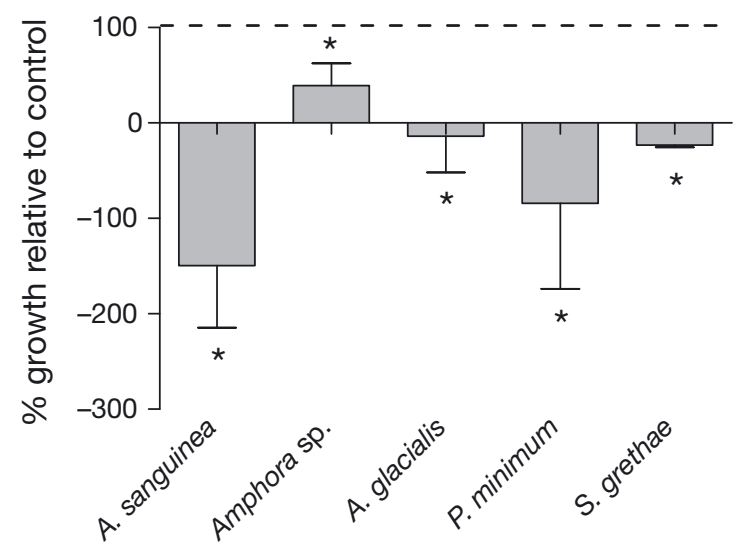

Fig. 1. Effects of Karenia brevis (strain CCMP 2228) extracellular extracts on the growth of 5 Gulf of Mexico phytoplankton species (Akashiwo sanguinea, Amphora sp., Asterionellopsis glacialis, Prorocentrum minimum, and Skeletonema grethae) over $48 \mathrm{~h}$ (except A. sanguinea, studied over $96 \mathrm{~h}$ ). Dashed line indicates growth equivalent to controls. $\left({ }^{*}\right)$ Growth significantly different from controls (1-way ANOVA with Tukey's post hoc test, $\mathrm{p} \leq 0.05, \mathrm{n}=7$, except $\mathrm{n}=6$ for $A$. sanguinea). Error bars indicate $1 \mathrm{SE}$
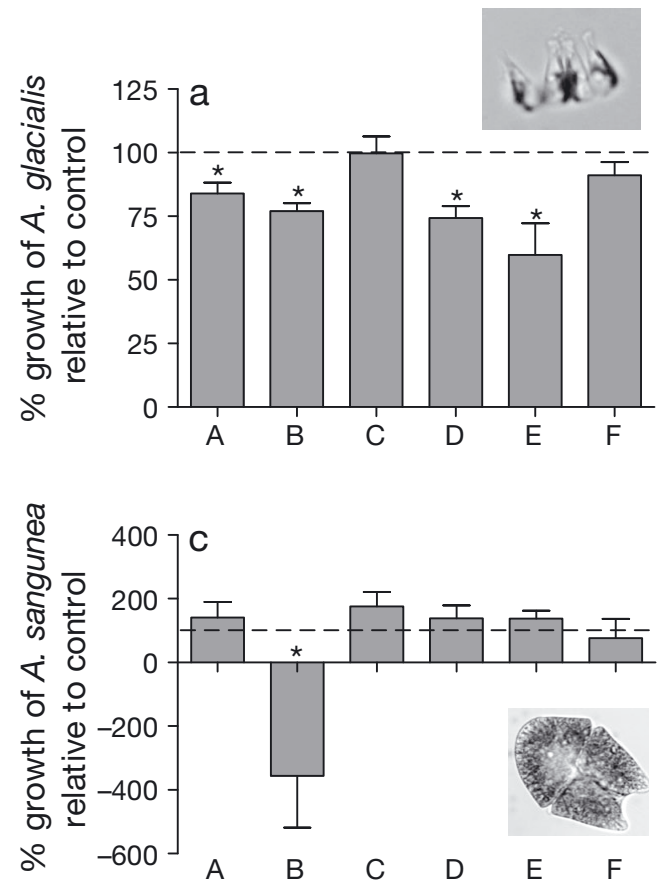

0.001 vs. Controls; Fig. 1). Dinoflagellates Akashiwo sanguinea and Prorocentrum minimum appeared to be the most sensitive of the competitors tested, with substantial mortality occurring over 96 and $48 \mathrm{~h}$, respectively ( $\mathrm{p}<0.001$ for both; Fig. 1). K. brevis was therefore allelopathic towards all 5 competitor species tested.

\section{Species-specificity of allelopathic compounds}

Competitor species were differentially affected by allelopathic compounds released by Karenia brevis 2228. Initially, we generated 9 fractions by HPLC separation of allelopathic $K$. brevis extracellular extracts, of which 2 fractions were allelopathic to 4 of the 5 competitor species; the diatom Amphora sp. was not significantly inhibited by either of these fractions (data not shown). Brevetoxins were not detected in either of these allelopathic fractions, as determined by liquid chromatography/mass spectrometry (LC-MS) analysis (data not shown). These 2 fractions yielded 6 compounds (A to F), with variable allelopathic effects on 4 competitor species (Fig. 2). Compound B was allelopathic to Asterionellopsis glacialis, Skeletonema grethae, Prorocentrum minimum, and Akashiwo sanguinea $(77,73,54$, and $-356 \%$ growth relative to controls, respectively). Sensitivity to other $K$. brevis
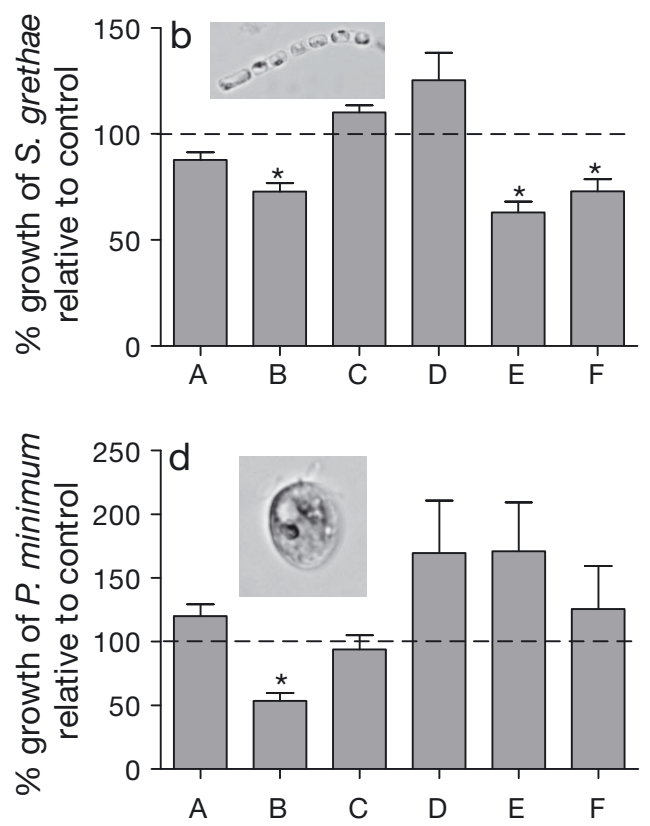

Fig. 2. Allelopathic effects of lipophilic Karenia brevis (strain CCMP 2228) compounds A to F on the growth of the diatoms (a) Asterionellopsis glacialis and (b) Skeletonema grethae and the dinoflagellates (c) Akashiwo sanguinea and (d) Prorocentrum minimum. Inset in each panel shows a light microscopic image of the respective species. Dashed line indicates growth equivalent to controls. $\left({ }^{*}\right)$ Growth significantly different $(\mathrm{p} \leq 0.05)$ from controls after $48 \mathrm{~h}$ for A. glacialis, S. grethae, and P. minimum, and after $96 \mathrm{~h}$ for $A$. sanguinea ( $\mathrm{n}=7$ for all). Error bars indicate $1 \mathrm{SE}$ 
compounds varied among competitor species. For example, A. glacialis suffered negative effects from compounds A, B, D, and E whereas $S$. grethae was harmed by compounds B, E, and F (Fig. 2).

\section{Plankton community responses to Karenia brevis allelopathy}

In the microcosm study using a natural $<150 \mu \mathrm{m}$ plankton assemblage from the Gulf of Mexico, Karenia brevis allelopathy was not evident. Contrary to laboratory-based results, allelopathic K. brevis 2228 extracts did not significantly kill or suppress growth of any phytoplankton groups analyzed (Fig. 3). When comparing the effects of $K$. brevis versus seawater extracts on growth of diatoms over $48 \mathrm{~h}, K$. brevis 2228 was neither allelopathic nor stimulatory towards chain or pennate diatoms, and $K$. brevis TxB3 was significantly stimulatory to chain diatoms, but did not affect pennate diatoms (1-way ANOVA, p < 0.05). Pennate diatoms grew substantially over $48 \mathrm{~h}$ in all treatments, including those exposed to seawater extracts (Fig. 3). Chain diatoms grew when exposed to $K$. brevis extracts, but not when exposed to seawater controls (Fig. 3). Concentrations of dinoflagellates and microzooplankton were not significantly altered regardless of the $K$. brevis extract to which they were exposed, although microzooplankton exposed to only seawater extract decreased in abundance (Fig. 3).

At the start of the microcosm experiment, chain diatoms of the genus Skeletonema were the dominant diatoms observed, accounting for $72 \%$ of diatom cells counted. After 48 h, Skeletonema spp. were still the dominant diatoms in all treatments, accounting for 53 to $80 \%$ of diatom cells. Other major diatoms belonged to the genera Pseudo-nitzchia, Chaetoceros, Coscinodiscus, and Cylindrotheca, although none of these groups ever accounted for $>10 \%$ of the total diatom community at either time point (data not shown). Overall, diatoms from the Florida assemblage were not harmed by exposure to Karenia brevis extracts (Fig. 3).

\section{Competitor co-cultures respond differently to Karenia brevis allelopathy}

In an experiment utilizing pooled Karenia brevis 2228 extract that was previously shown to be allelopathic to Asterionellopsis glacialis (data not shown), growth of the diatom $A$. glacialis in monoculture was inhibited by $76 \%$ compared to controls ( $<<0.001$ ), but Skeletonema grethae in monoculture was not affected (Fig. 4a). When exposed to the same K. brevis 2228 extract in co-culture, growth of both A. glacialis and $S$. grethae was suppressed ( $\mathrm{p}<0.0001$, Fig. 4a), with proportions of $A$. glacialis and $S$. grethae remaining unchanged in both treatments and controls (Fig. 4b). S. grethae constituted approximately $57 \%$ of all cells in co-culture, whether exposed or unexposed to $K$. brevis allelopathy.

\section{Importance of competitor cell concentra- tion and growth stage in Karenia brevis allelopathy}

When exposed to Karenia brevis 2228 extracts used in the co-culture experiment, growth of Skeletonema grethae at low and medium initial cell concentrations was significantly inhibited after $48 \mathrm{~h}(\mathrm{p}=0.046$ and 0.0023, respectively; Fig. 4c). $S$. grethae at initial concentrations similar to those used in the monocultures of the coculture experiment (see previous section) were not affected by exposure to $K$. brevis 2228 extracts ( $p=0.46$; Fig. 4c). Significant differences between the growth of $S$. grethae control cultures at all 3 concentrations were also detected ( $\mathrm{p}<0.05,1$-way ANOVA; Fig. 4c).
Fig. 3. Population densities of a natural Florida plankton assemblage of (a) chain diatoms, (b) pennate diatoms, (c) dinoflagellates, and (d) microzooplankton after $48 \mathrm{~h}$ exposure to seawater extracts (control), Karenia brevis allelopathic extracts (strain CCMP 2228), or K. brevis non-allelopathic extracts (strain TxB3). $\left({ }^{*}\right)$ Cell concentration significantly different ( $t$-test, $\mathrm{p}<0.05, \mathrm{n}=6$ ) from $0 \mathrm{~h}$ to $48 \mathrm{~h}$. Error bars indicate $1 \mathrm{SE}$ 

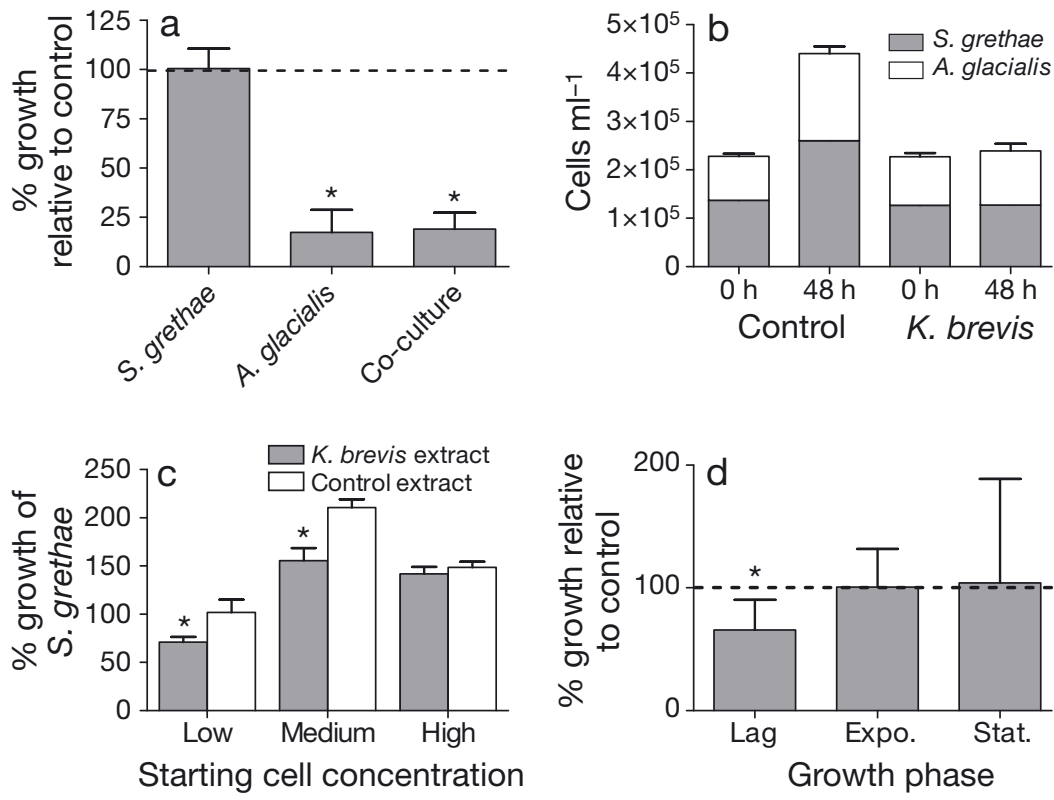

Fig. 4. Effects of Karenia brevis (strain CCMP 2228) extracellular extracts after $48 \mathrm{~h}$ exposure on (a) monocultures and co-cultures and (b) co-cultures only of Asterionellopsis glacialis and Skeletonema grethae; (c) S. grethae of varying starting cell concentrations; and (d) $S$. grethae cells at different growth stages Expo.: exponential growth; Stat.: stationary) normalized to the same cell concentration. Dashed line indicates growth equivalent to controls. $\left({ }^{*}\right)$ Significant differences between treatments and controls (unpaired $t$-test, $\mathrm{p}<0.05$ ). Error bars indicate $1 \mathrm{SE}$

Growth of Skeletonema grethae at different growth stages was differentially affected by the addition of Karenia brevis 2228 extracts, even when the initial cell concentration of $S$. grethae was held constant (Fig. 4d). Growth of $S$. grethae in lag phase was significantly inhibited by $K$. brevis 2228 extracts ( $p=0.028)$, whereas growth of $S$. grethae from both exponential and stationary growth phases was not significantly inhibited compared to controls (Fig. 4d).

\section{DISCUSSION}

\section{Different Karenia brevis compounds are allelopathic to different competitors}

Karenia brevis produces a suite of allelopathic compounds, some of which inhibit multiple competitors and others that are allelopathic only towards certain species (Fig. 2). Purification of several compounds from $K$. brevis 2228 extracellular extracts led to 1 compound (B) that was allelopathic towards 4 of the 5 phytoplankton species tested, including 2 diatoms and 2 dinoflagellates (Fig. 2). Additionally, compound E inhibited the growth of the diatoms Skeletonema grethae and Asterionellopsis glacialis, Fig. 2a,b). S. grethae was also inhibited by compound F, whereas A. glacialis was inhibited by compounds A and D. The diatom Amphora sp. was not inhibited by any $K$. brevis HPLC fractions collected (data not shown), despite being inhibited by crude extracellular extracts of $K$. brevis, which could suggest synergistic effects of $K$. brevis compounds against certain competitors or decomposition of compounds that are allelopathic towards Amphora sp. These results demonstrate that not all diatom taxa are equally susceptible to the same allelopathic compounds (Fig. 2a,b). In contrast, the dinoflagellates tested in the present study (Akashiwo sanguinea and Prorocentrum minimum) were only inhibited by a single compound, B (Fig. 2c,d). In addition to the compounds tested in the present study, $K$. brevis produces highly potent, water-soluble, unstable allelopathic compounds (Prince et al. in press) that inhibit the same 4 competitors in the present study (data not shown). To date we have not been successful in identifying the full molecular structures of allelopathic compounds from $K$. brevis, although lipophilic compounds employed in the present study have molecular weights of 500 to $1000 \mathrm{Da}$ and possess aromatic functional groups (Prince et al. in press). Since $K$. brevis is likely to be exposed to multiple competitor species in a natural assemblage, it could be beneficial to produce multiple allelopathic compounds in order to ensure a competitive advantage.

Because allelopathic compounds produced by phytoplankton have only rarely been identified (e.g. Windust et al. 1996, Bachvaroff et al. 2008), determining whether a single compound is allelopathic to multiple species or whether multiple allelopathic compounds are produced with species-specific effects has been difficult. However, competitors clearly differ in susceptibility to allelopathic compounds. For example, karlotoxins produced by the mixotrophic dinoflagellate Karlodinium micrum inhibited the growth of some competitors, including the cryptophytes Storeatula major and the raphidophyte Heterosigma akashiwo, but did not inhibit the cryptophytes Pyrenomonas salina or the dinoflagellate Amphidinium carterae (Adolf et al. 2006). Similar patterns have been found for other allelopathic phytoplankton, including dinoflagellates Alexandrium spp. (Fistarol et al. 2004, Tillmann \& Hansen 2009), the haptophyte Prymnesium parvum (Fistarol et al. 2003), and Karenia brevis 
(Kubanek et al. 2005, Prince et al. 2008a). Kubanek et al. (2005) found that some filtrates of Karenia brevis were allelopathic to some species and other filtrates were allelopathic to others, also suggesting that allelopathy may be mediated by several speciesspecific compounds. These examples suggest that competitors vary in susceptibility to filtrates or crude extracts containing multiple compounds released by an allelopathic species, but they do not tease apart whether this is due to compounds that target different competitors, or to inherent differences in competitor susceptibility to a single allelopathic compound. The present study demonstrates that different compounds are responsible for the varying susceptibility of different species to Karenia brevis allelopathy.

\section{Allelopathic effects of Karenia brevis are dampened in a complex ecological community}

Although experiments with individual competitor species demonstrated that Karenia brevis 2228 is allelopathic towards multiple competitors (Figs. 1 \& 2), these extracts did not kill or significantly inhibit the growth of phytoplankton in a natural community assemblage (Fig. 3), and the non-allelopathic $K$. brevis strain TxB3 significantly stimulated the growth of chain diatoms. It is possible that extracts from $K$. brevis 2228 (previously shown to be allelopathic to Asterionellopsis glacialis) had a slight allelopathic effect on the plankton assemblage, but stimulation from trace amounts of organic nitrogen, phosphorus, or vitamins extracted with $K$. brevis exudates may have been sufficient to outweigh inhibitory effects. When exposed to extracts from the non-allelopathic TxB3 strain, such a stimulatory effect would be more obvious, as seen in Fig. 3a, since there would be no counteracting allelopathic effect. The assemblage was collected at a site where $K$. brevis has been previously observed (K. L. Poulson pers. obs.); therefore the potential for phytoplankton from this site to evolve resistance to $K$. brevis allelopathy cannot be excluded. These stimulatory effects would be expected to be more pronounced when studying a resource-limited natural assemblage compared to a laboratory culture grown under nutrient-replete conditions. Similar results were found in another microcosm study, in which filtrates from 3 cyanobacterial species were stimulatory towards multiple community members, whereas in laboratorybased studies, these competitors were inhibited (Suikkanen et al. 2005). This highlights the difficulty in separating the effects of exploitation competition and interference competition (i.e. allelopathy) in more complex natural settings, as opposed to highly controlled laboratory experiments.

\section{Identity and population density of dominant commu- nity member may affect outcome of allelopathy}

The ability of some competitors to undermine Karenia brevis allelopathy (Prince et al. 2008b) could also explain the lack of observed allelopathy for the natural assemblage used in the present study. Our Florida phytoplankton plankton assemblage was dominated by members of the genus Skeletonema, one of which (S. grethae) had previously been shown to reduce the allelopathic potency (towards $S$. grethae) of $K$. brevis cultures and field samples by an unknown mechanism (Prince et al. 2008b). Among 2005 and 2006 Florida field collections all dominated by $K$. brevis, the presence of Skeletonema spp. appeared to be associated with less allelopathic samples (Prince et al. 2008b). However, whether Skeletonema spp. protect other phytoplankton from $K$. brevis allelopathy is unknown. In the present study, the lack of an inhibitory effect of $K$. brevis extracts towards the natural phytoplankton assemblage could have been due to Skeletonema spp. undermining $K$. brevis allelopathy towards the phytoplankton assemblage at large. Since our Gulf of Mexico field assemblages were dominated by Skeletonema spp., we wanted to test how allelopathic outcomes are affected by interactions among competitor species.

To determine how phytoplankton are affected by allelopathy when in the presence of other phytoplankton species, we tested allelopathic effects of Karenia brevis on co-cultures of Skeletonema grethae and another susceptible competitor which may undermine $K$. brevis allelopathy as well, the diatom Asterionellopsis glacialis (Prince et al. 2008b). In co-culture, both diatoms were similarly inhibited by $K$. brevis 2228 extracts, although in this experiment $S$. grethae was not inhibited when grown alone (Fig. 4a,b). Rather than implying a protective effect with allelopathy being undermined by one of these species, the enhanced susceptibility of $S$. grethae in co-culture may be related to the initial population density of this diatom, since initial cell concentrations of $S$. grethae grown alone were twice that of $S$. grethae grown in coculture with A. glacialis.

\section{Competitor population density and physiological state determine effects of Karenia brevis allelopathy}

The population density of competitors is known to be important in allelopathic interactions. Allelopathic effects of the dinoflagellate Alexandrium ostenfeldii were minimized when competitor population density was high, suggesting a possible saturation effect whereby individual cells adsorb or absorb allelopathic compounds, mitigating their damage towards other cells 
(Tillmann et al. 2007). Similarly, lytic effects of the mixotrophic haptophyte Prymnesium parvum towards the dinoflagellate Oxyrrhis marina were decreased in response to increased $O$. marina cell concentrations (Tillmann 2003). In the present study, Skeletonema grethae of higher initial concentration was less susceptible to Karenia brevis allelopathic extracts than $S$. grethae of low or medium cell concentration (Fig. 4c), complementing the findings of Tillmann et al. (2007). However, cell concentrations of Skeletonema spp. within our natural plankton assemblage were lower than any of the concentrations used in the experiment in which we varied initial $S$. grethae concentration, yet field-collected chain diatoms (dominated by Skeletonema spp.) were resistant to K. brevis 2228 allelopathy. Additionally, the growth of chain diatoms in the assemblage was stimulated when exposed to $K$. brevis TxB3 extracts, perhaps from trace amounts of organic nutrients and vitamins extracted from the culture media. This stimulatory effect of $K$. brevis extracts suggests that diatoms were nutrient-limited in the field, and therefore in a physiological state analogous to stationary growth. If stationary-phase phytoplankton are less susceptible to $K$. brevis allelopathy than more physiologically active cells, this could explain the lack of observed allelopathy in the microcosm experiment.

In support of the hypothesis that growth stage is important to sensitivity towards allelopathy, Skeletonema grethae was most sensitive to Karenia brevis 2228 extracts in lag phase, and, in this experiment, not sensitive in exponential growth or stationary phase, even though cultures were normalized to the same starting cell concentrations (Fig. 4d). This indicates that varying physiological states associated with these different growth stages are important factors in determining $S$. grethae sensitivity to allelopathy. S. grethae cells may produce and release stage-specific compounds that defend cells from $K$. brevis allelopathic compounds. $S$. marinoi produces a wide variety of metabolites at specific growth stages, and exudates of this species have been shown to affect the growth and cellular functions of other phytoplankton species (Barofsky et al. 2009, Paul et al. 2009). The possibility that $S$. grethae also produces stage-specific compounds that are capable of defending against or undermining $K$. brevis allelopathy warrants further study. Alternatively, cells in lag phase may suffer from a trade-off between certain cellular functions and the ability to defend themselves from allelopathic compounds produced by $K$. brevis. Finally, the difference in cell-surface area-to-volume ratio of cells and/or chains of $S$. grethae at these different growth stages may also dictate how susceptible these cells are to allelopathic compounds. Specifically, allelopathic compounds may more rapidly contact potential cellular tar- gets of smaller $S$. grethae cells or chains. It may also benefit $K$. brevis to produce multiple compounds if competitor cells from natural assemblages are in different physiological states and these different cells vary in their sensitivity to allelopathy.

\section{CONCLUSIONS}

The dinoflagellate Karenia brevis produces multiple compounds that are allelopathic towards several phytoplankton species, but it is evident that competitors are susceptible to slightly different suites of compounds. Competitor growth stage and cell concentration appear to play important roles in determining the effectiveness of $K$. brevis allelopathic compounds, with cells in lag phase more susceptible to $K$. brevis allelopathy than cells in later growth stages. The relative resistance of stationary phase cells may explain why phytoplankton in the nutrient-limited microcosm experiment did not suffer allelopathic effects of $K$. brevis. It may be advantageous for $K$. brevis to produce multiple allelopathic compounds if a diverse chemical arsenal provides protection against a variety of phytoplankton competitors under a range of ecological conditions. However, the effects of $K$. brevis allelopathy in the field may be mild relative to the growth inhibition observed in nutrient-replete laboratory experiments. Although pair-wise laboratory experiments can be useful in permitting a deeper understanding of mechanistic aspects of competitive interactions, they may not accurately predict ecological outcomes in the field when one considers the complexity of multi-species interactions.

Acknowledgments. We thank L. Campbell for providing Karenia brevis strain TxB3, T. Ellestad and N. Goodyear for assistance in the field, and $\mathrm{K}$. Wolfe for assistance in the laboratory. This research was supported by National Science Foundation (NSF) grants OCE-0134843 and OCE-0726689 to J.K. as well as NSF IGERT 'Signals in the Sea' Fellowships awarded to E.K.P., K.L.P., and R.D.S.

\section{LITERATURE CITED}

Adolf JE, Bachvaroff TR, Krupatkina DN, Nonogaki H and others (2006) Species specificity and potential roles of Karlodinium micrum toxin. Afr J Mar Sci 28:415-419

Bachvaroff TR, Adolf JE, Squier AH, Harvey HR, Place AR (2008) Characterization and quantification of karlotoxins by liquid chromatography-mass spectrometry. Harmful Algae 7:473-484

Barofsky A, Vidoudez C, Pohnert G (2009) Metabolic profiling reveals growth stage variability in diatom exudates. Limnol Oceanogr Methods 7:382-390

Fistarol GO, Legrand C, Granéli E (2003) Allelopathic effect of Prymnesium parvum on a natural plankton community. Mar Ecol Prog Ser 255:115-125 
Fistarol GO, Legrand C, Selander E, Hummert C, Stolte W, Granéli E (2004) Allelopathy in Alexandrium spp.: effect on a natural plankton community and on algal monocultures. Aquat Microb Ecol 35:45-56

Flewelling LJ, Naar JP, Abbott JP, Baden DG and others (2005) Red tides and marine mammal mortalities. Nature 435:755-756

Flynn KJ (2008) Attack is not the best form of defense: lessons from harmful algal bloom dynamics. Harmful Algae 8: 129-139

Graneli E, Salomon PS (2010) Factors influencing allelopathy and toxicity in Prymnesium parvum. J Am Water Resour Assoc 46:108-120

Hansen E, Eilertsen HC (2007) Do the polyunsaturated aldehydes produced by Phaeocystis pouchetii (Hariot) Lagerheim influence diatom growth during the spring bloom in northern Norway? J Plankton Res 29:87-96

Jonsson PR, Pavia H, Toth G (2009) Formation of harmful algal blooms cannot be explained by allelopathic interactions. Proc Natl Acad Sci USA 106:11177-11182

Kubanek J, Hicks MK, Naar J, Villareal TA (2005) Does the red tide dinoflagellate Karenia brevis use allelopathy to outcompete other phytoplankton? Limnol Oceanogr 50: 883-895

Landsberg JH, Flewelling LJ, Naar J (2009) Karenia brevis red tides, brevetoxins in the food web, and impacts on natural resources: decadal advancements. Harmful Algae 8: 598-607

Paul C, Barofsky A, Vidoudez C, Pohnert G (2009) Diatom exudates influence metabolism and cell growth of cocultured diatom species. Mar Ecol Prog Ser 389:61-70

Plakas SM, El Said KR, Jester ELE, Granade HR, Musser SM, Dickey RW (2002) Confirmation of brevetoxin metabolism in the eastern oyster (Crassostrea virginica) by controlled exposures to pure toxins and to Karenia brevis cultures. Toxicon 40:721-729

Poulson KL, Sieg RD, Kubanek J (2009) Chemical ecology of the marine plankton. Nat Prod Rep 26:729-745

Prince EK, Lettieri L, McCurdy KJ, Kubanek J (2006) Fitness consequences for copepods feeding on a red tide dinoflagellate: deciphering the effects of nutritional value, toxicity, and feeding behavior. Oecologia 147:479-488

Prince EK, Myers TL, Kubanek J (2008a) Effects of harmful algal blooms on competitors: allelopathic mechanisms of the red tide dinoflagellate Karenia brevis. Limnol Oceanogr 53:531-541

Prince EK, Myers TL, Naar J, Kubanek J (2008b) Competing phytoplankton undermines allelopathy of a bloom-forming dinoflagellate. Proc Biol Sci 275:2733-2741

Editorial responsibility: Joseph Pawlik, Wilmington, North Carolina, USA
Prince EK, Poulson KL, Myers TL, Sieg RD, Kubanek J (in press) Characterization of allelopathic compounds from the red tide dinoflagellate Karenia brevis. Harmful Algae doi:10.1016/j.hal.2010.06.003

Ribalet F, Berges JA, Ianora A, Casotti R (2007) Growth inhibition of cultured marine. phytoplankton by toxic algalderived polyunsaturated aldehydes. Aquat Toxicol 85: $219-227$

Suikkanen S, Fistarol GO, Granéli E (2005) Effects of cyanobacterial allelochemicals on a natural plankton community. Mar Ecol Prog Ser 287:1-9

Suikkanen S, Engstrom-Ost J, Jokela J, Sivonen K, Viitasalo M (2006) Allelopathy of Baltic Sea cyanobacteria: no evidence for the role of nodularin. J Plankton Res 28:543-550

Tester PA, Steidinger KA (1997) Gymnodinium breve red tide blooms: initiation, transport, and consequences of surface circulation. Limnol Oceanogr 42:1039-1051

> Tillmann U (2003) Kill and eat your predator: a winning strategy of the planktonic flagellate Prymnesium parvum. Aquat Microb Ecol 32:73-84

Tillmann U, Hansen PJ (2009) Allelopathic effects of Alexandrium tamarense on other algae: evidence from mixed growth experiments. Aquat Microb Ecol 57:101-112

Tillmann U, John U, Cembella A (2007) On the allelochemical potency of the marine dinoflagellate Alexandrium ostenfeldii against heterotrophic and autotrophic protists. J Plankton Res 29:527-543

Tillmann U, Alpermann T, John U, Cembella A (2008) Allelochemical interactions and short-term effects of the dinoflagellate Alexandrium on selected photoautotrophic and heterotrophic protists. Harmful Algae 7:52-64

- Uronen P, Kuuppo P, Legrand C, Tamminen T (2007) Allelopathic effects of toxic haptophyte Prymnesium parvum lead to release of dissolved organic carbon and increase in bacterial biomass. Microb Ecol 54:183-193

> Vardi A, Schatz D, Beeri K, Motro U, Sukenik A, Levine A, Kaplan A (2002) Dinoflagellate-cyanobacterium communication may determine the composition of phytoplankton assemblage in a mesotrophic lake. Curr Biol 12:1767-1772

Windust AJ, Wright JLC, McLachlan JL (1996) The effects of the diarrhetic shellfish poisoning toxins, okadaic acid and dinophysistoxin-1, on the growth of microalgae. Mar Biol 126:19-25

Yamasaki Y, Shikata T, Nukata A, Ichiki S and others (2009) Extracellular polysaccharide-protein complexes of a harmful alga mediate the allelopathic control it exerts within the phytoplankton community. ISME J 3:808-817

Zar JH (1999) Biostatistical analysis, 4th edn. Prentice Hall, Upper Saddle River, NJ

Submitted: May 21, 2010; Accepted: August 23, 2010

Proofs received from author(s): September 29, 2010 